\title{
Sensorineural hearing loss after bacterial meningitis in children
}

\author{
Aliya Seidullayeva ${ }^{1,2}$, Gulnar Zhaxylykova ${ }^{1}$, Dinagul Bayesheva, ${ }^{2}$, \\ Raisa Sundetova $^{1,2}$, Bulat Aitzhanov ${ }^{3}$, Almagul Orymbayeva ${ }^{1,4}$
}

${ }^{I} J C S$ «Medical university Astana», Astana, Kazakhstan ${ }^{2} R P O$ «Infectious disease of specialists society», Astana, Kazakhstan

${ }^{3} U M C$ «National children's rehabilitation center», Astana, Kazakhstan

${ }^{4} L L P \ll$ Almaton-2», Astana, Kazakhstan

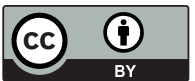

This work is licensed under Creative Commons Attribution 4.0 International License

J Clin Med Kaz 2017;4(46):14-19

Автор для корреспонденции: Сейдуллаева Алия Жалдыбаевна- phD докторант кафедры детских инфекционных болезней $\mathrm{AO}$ «Медицинский университет Астана. Адрес: г.Астана, ул.Т.Рыскулова 12. Тел.: +7 70118603 03. E-mail: seidullayeva.aliya@gmail.com

\section{Abstract}

Sensorineural hearing loss - form of hearing loss up to its total lossat which any of the sites of the sound-receiving part can be damaged. The most important problem of patients with sensorineural hearing loss is lack of effective treatment and inability to restore hearing because $80 \%$ of patients who suffered from bacterial meningitis loss of hearing is accompanied by ossification of internal ear structures. However, bacterial meningitis is still registered in Kazakhstan and is a reason of development of sensorineural hearing loss and often accompanied byossification of internal ear structures in children and adults leading to longterm neurological lesions, such as hearing impairments or hearing loss. For early diagnosis of hearing loss in children with bacterial meningitis, an audiological examination should be performed in the first 48 hours from the onset of the diseaseand after discharge from the hospital for 1 year. To date, the only effective method of hearing restoration is surgery - cochlear implantation. This review of the literature is devoted to one of the actual complications of bacterial meningitis - sensorineural deafness in children.

Keywords: bacterial meningitis, sensorineural hearing loss, children, S.pneumoniae, H.influenzae, N.meningitidis.

\section{БАЛАЛАРДАҒЫ БАКТЕРИАЛДЫҚ МЕНИНГИТТЕН КЕЙІНГІ НЕЙРОСЕНСОРЛЫК КЕРЕНДІК}

Алия Сейдуллаева ${ }^{1,2}$, Гульнар Жаксылыкова ${ }^{1}$, Динагуль Баешева ${ }^{1,2}$,

Раиса Сундетова ${ }^{1,2}$, Болат Айтжанов ${ }^{3}$, Алмагуль Орумбаева ${ }^{1,4}$

${ }^{1}$ «Астана медицина университеті» АҚ, Астана, Қазақстан

${ }^{2}$ «Инфекционист дәрігерлер қоғамы» АҚБ, Астана, Қазақстан

${ }^{3} \mathrm{UMC}$ «Балаларды оңалтудың ұлттық орталығы»,

Астана, Қазақстан

${ }^{4} Ж Ш С$ «Алматон-2», Астана, Қазақстан

\section{ТҰЖЫРЫМДАМА}

Нейросенсорлық кереңдік-естуді қабылдайтын анализатордың қандай да бір бөлімінің зақымдалу әсерінен есту қабілетінің толық жоғалуы. Нейросенсорлық кереңдікпен сыртқаттанған науқастастардың негізгі мәселесі тиімді емнің болмауы және есту қабілетін қалыпқа келтірудің қиындығы болып табылады. Өйткені, бактериалдық менингитпен ауырған 80\% науқастарда естудің жоғалуы ішкі құлақ оссифрикациясымен байқалады. Бірақ, Қазақстанда бактериалдық менингит аурушаңдылығы әлі де тіркеледі және балалар мен ересектерде нейросенсорлық кереңдіктің себебі болып табылады, сонымен қатар ұзақ мерзімді есту қабілетінің төмендеуі немесе естудің жоғалуы сияқты неврологиялық асқынуларға алып келеді. Балалардағы бактериалдық менингиттен кейінгі есту қабілетінің жоғалуын ерте анықтау үшін, аурудың басталуынан бастап алғашқы 48 сағатта және ауруханадан емделіп шыққаннан кейін 1 жыл ішінде аудиологиялық тексеру жүргізу қажет. Қазіргі таңда естуді қалпына келтірудің ең тиімді әдісі ота арқылы - кохлеарлы имплантацияны жасау болып табылады. Берілген әдебиетке шолуда балалардағы бактериальдық менингиттен кейінгі негізгі асқынулардың бірі нейросенсорлықкереңдікке арналған.

Маңызды сөздер: бактериалдық менингит, нейросенсорлық кереңдік, балалар, пневмококк, гемофилдік таяқша, менингококк.

\section{НЕЙРОСЕНСОРНАЯ ТУГОУХОСТЬПОСЛЕ ПЕРЕНЕСЕННЫХ БАКТЕРИАЛЬНЫХ МЕНИНГИТОВ У ДЕТЕЙ} Алия Сейдуллаева ${ }^{1,2}$, Гульнар Жаксылыкова ${ }^{1}$, Динагуль Баешева ${ }^{1,2}$, Раиса Сундетова ${ }^{1,2}$, Болат Айтжанов ${ }^{3}$, Алмагуль Орумбаева $^{1,4}$ 
PЕЗЮME

Нейросенсорная тугоухость - форма снижения слуха вплоть до его полной утраты, при которой поражаются какие-либо из участков звуковоспринимающего отдела слухового анализатора. Важной проблемой больных с нейросенсорной тугоухостью является отсутствие эффективного лечения и невозможность восстановления слуха, так как у 80\% пациентов, перенесших бактериальный менингит, потеря слуха сопровождается оссификацией структур внутреннего уха. Однако, бактериальные менингиты все еще регистрируется в Казахстане и является причиной развития нейросенсорной тугоухости у детей и взрослых, нередко сопровождаясь оссификацией структур внутреннего уха и приводя к долгосрочным неврологическим поражениям, таким, как нарушение слуха или потеря слуха. Для ранней диагностики потери слуха у детей при бактериальном менингите необходимо проведение аудиологического обследования в первые 48 часов от начала заболевания и после выписки в течение 1 года. На сегодняшний день, единственным эффективным методом восстановления слуха является оперативное вмешательство - кохлеарная имплантация. Предполагаемый обзор литературы посвящен одному из актуальных осложнений бактериальных менингитов-нейросенсорной тугоухости у детей.

Ключевые слова: бактериальный менингит, нейросенсорная тугоухость, дети, пневмококк, гемофильная палочка, менингококк.

\section{Введение}

На современном этапе бактериальные менингиты (БМ) являются актуальной проблемой клинической педиатрии [1]. БМ продолжают оставаться основной причиной заболеваемости и смертности у детей до 5 лет во всем мире $[1,2]$. По литературным данным БМ вызывает частичную или полную потерю слуха в 10-20\% случаев [3]. Частота потери слуха после перенесенного БМ различна, для возбудителей S.pneumoniae составляет $31-36 \%$, N.meningitidis $8-11 \%$ и H.influenzae 6-11\% случаев [4]. По данным Ванде Бик [3] риск потери слуха при БМ, вызванной S.pneumoniae, составляет 22\% и 8\%-N.meningitides [5]. По мнению других авторов у пациентов с БМ 5-35\% развивается нейросенсорная тугоухость (НСТ), из них у 4\% пациентов развивается глубокая двусторонняя НСТ [6,7]. Однако, НСТ клинически не всегда выявляется, поэтому потеря слуха остается не диагностированной в течение длительного периода времени. Особенно, сложно поставить диагноз НСТ маленьким детям до 3 лет, так как у них нарушение слуха может быть выявлено в поздний период либо родителями, либо во время специализированного обследования. Потеря слуха отрицательно влияет на развитие речи и психомоторное развитие ребенка [8]. По литературным данным в 25-30\% случаев у детей, перенесших БМ, нарушение слуха не выявляется своевременно [7,8].

Цель исследования: Провести обзор литературы по осложнению бактериальных менингитов у детей в виде нейросенсорной тугоухости.

\section{Методы исследования:}

Проведен систематический обзор с элементами индуктивно-дедуктивного анализа. Были использованы библиографические и наукометрические базы данных: Thomson Reuters (WebofScience), SpringerLink (SpringerNature), Elsevier (Science Direct), PubMed (MedLine), Cochrane Library.

\section{Результаты и обсуждение}

Литературные данные свидетельствуют о том, что на современном этапе БМ у детей представляют серьезную проблему в педиатрической практике, так как у одного из пяти пациентов с БМ формируются такие неврологические осложнения, как нейросенсорная тугоухость, судороги, нарушение движения, гидроцефалия, другие когнитивные и поведенческие нарушения $[9,10,11,12,13]$. Установлено, что менингит, вызванный S.pneumoniae, отличается неблагоприятным прогнозом, который приводит к наибольшей смертности, а у 30\% выживших вызывает глубокую потерю слуха [12,13]. Широкое применение современных антибактериальных препаратов, появление вакцин против гемофильной палочки, пневмококка и менингококка существенно снизили уровень летальности от бактериальных менингитов у детей. В странах с активной программой иммунизации использование Нib и пневмококковой вакцин способствовало снижению заболеваемости БМ, вызванных гемофильной палочкой и пневмококковой инфекцией $[1,14]$. Так, применение Хибвакцины в Республике Малави Восточной Африки (по данным Daza P и др 2006) явилось причиной снижения заболеваемости на $100 \%$ (показатель заболеваемости 20-40 на 100 тыс. населения среди детей до 5 лет в 1997-2002 годах снизился до 0 в 2003-2004 годах). Высокая эпидемиологическая эффективность внедрения специфической вакцинопрофилактики среди детей до 5 лет отмечена многими авторами, при этом снижение показателей заболеваемости, по данным отдельных исследователей, колеблется от 50\% до 100\% [15]. Показатели заболеваемости БМ, вызванные S.pneumoniae, в развитых странах составляют 1-2 случая на 100 тыс. населения, а в развивающихся - 20 на 100 тыс.населения. По официальной информации Всемирной организации здравоохранения 1,6 миллионов людей ежегодно умирают от пневмококковых заболеваний, в том числе 0,7-1 миллион детей в возрасте до 5 лет в основном из развивающихся стран [14,16,17].

Дети с БМ подвергаются высокому риску развития потери слуха. В литературе приводятся разные данные, так, согласно A. Davisu K. Davis, потери слуха варьируются от 2-31\% [18], хотя данные мета-анализа L.J.Baraff [19], Chandran и др. [20], а также исследование, проведенное в Канаде [21], свидетельствуют о том, что заболеваемость с постоянным нарушением слуха ближе к 10\%. Исследования пациентов с нейросенсорной тугоухостью, проведенные D.Philippon с соавторами в 2010 году с использованием компьютерной томографии височных костей (КТ), установили, что более выраженная степень оссификации улитки чаще определяется после перенесенного менингита, вызванного S.pneumoniay [22]. Воздействие эндотоксина S.pneumoniae, N.meningitidis, H.influenzae и распространение инфекции во внутреннее ухо через водопровод улитки или внутренний слуховой проход приводит к тяжелой степени потери слуха (глухоте) на ранней стадии менингита $[23,24]$.

Нейросенсорная тугоухость- форма снижения слуха вплоть до его полной утраты, при которой поражаются какие-либо из участков звуковоспринимающего отдела слухового анализатора, начиная от нейроэпителиальных структур внутреннего уха и заканчивая корковым представительством в височной доле коры головного мозга[22,25]. Важной проблемой больных с нейросенсорной тугоухостью является отсутствие эффективного лечения и невозможность восстановления слуха, так как у 80\% пациентов, перенесших БМ, потеря слуха сопровождается 
оссификацией структур внутреннего уха [26,27]. При БМ во внутреннем ухе происходят важные патоморфологические изменения, завершающим этапом которого является развитие оссификации улитки. Процесс развития оссификации улитки состоит из трех стадий: острая, фиброзная и стадия оссификации. Острая, которая совпадает с началом заболевания менингитом и характеризуется гнойным воспалением и образованием серозно-фиброзного экссудата в основном перилимфатическом пространстве, не поражая полости, заполненные эндолимфой [22]. Через 2 недели от начала инфекционного процесса развивается вторая стадия нейросенсорной тугоухости-фиброзная, которая сопровождается пролиферацией фибробластов в перилимфатических пространствах и начинается ангиогенез. Третья стадия нейросенсорной тугоухости завершается оссификацией. Оссификация улитки является патологическим формированием «новой кости»в просвете капсулы лабиринта, приводящей к стойкой потери слуха[24]. На стадии оссификации формируется костная ткань, которая в первую очередь обнаруживается в базальном завитке, начиная со второго месяца после развития лабиринтита. Формирование костной ткани, с последующей кальсификацией и ремоделированием, облитерирует как пери- так и эндолимфатические пространства. Поэтому до формирования оссификации улитки при БМ необходимо в наиболее ранние сроки выявить НСТ, чтобы рекомендовать пациентам КИ [27,29]. Доказано, что применение кортикостероидов (дексаметазон) до антибактериальной терапии при БМ снижает риск развития оссификации улитки [30].Однако, ограниченные возможности системы оказания высокотехнологичной помощи в РК, а также удаленность пациентов от центров КИ, не всегда позволяют проводить оперативные вмешательства в столь сжатые сроки [22,26].

Для установления НСТ после БМ необходимо провести ранний скрининг слуха по возможности в первые 48 часов от начала заболевания, методом отоакустической эмиссии. ОАЭ - это чрезвычайно слабые звуковые колебания, генерируемые наружными волосковыми клетками улитки. Задержанная вызванная отоакустическая эмиссия (ЗВОАЭ-скрининг) - очень быстрый, легко применимый, легко читаемый, относительно распространенный метод скринингового обследования слуха. При неблагоприятном результате ЗВОАЭ в виде: «Не прошел» проводится полное расширенное аудиологическое обследование. Расширенное аудиологическое обследование 2 вида ОАЭ: ЗВОАЭ (базовая) и на продукт искажения ОАЭ (ПИОАЭ), коротколатентные слуховые вызванные потенциалы (КСВП), тимпанометрию, МРТ и КТ улитки [26,30]. КСВП являются результатом биоэлектрического ответа внутренних волосковых клеток улитки, слухового нерва и ствола головного мозга в ответ на звуковой стимул. Слух считается нормальным, если порог регистрации КСВП менее 30 дБ. ОАЭ и КСВП можно зарегистрировать у детей раннего возраста и взрослых [32]. Тимпанометрия (акустическая импедансометрия) - метод объективного исследования функции среднего уха, степени подвижности барабанной перепонки и проводимости слуховых косточек (молоточек, наковальня, стремечко) путем создания вариаций давления воздуха в слуховом канале. Тимпанометрия позволяет выявить отсутствие порога акустического рефлекса, косвенно указывая на нарушение слуха. Тимпанометрия, ОАЭ и
КСВП совершенно безвредны для пациента и позволяют объективно оценить работу среднего уха, улитки, пороги слышимости и состояние слуховых путей даже у маленьких детей. Тональная аудиометрия - субъективный метод измерения остроты слуха, по результатам исследования можно диагностировать потерю слуха, но, к сожалению, не применимо у маленьких детей до 3-х лет. Преимуществом МРТ является возможность более точного определения стадии процесса (фиброз или оссификация) на основании распределения жидкости во внутреннем ухе [31,33]. С помощью МРТ можно выявить минимальные изменения, что является очень важным для своевременной диагностики и проведения операции до развития оссификации структур улитки [22, 33,34,40].

По опыту Голландии при НСТ аудиологическое обследование проводят неоднократно всем пациентам с БМ после выписки в течение 1 года. Два основных фактора, задержка развития речи и языка, а также неполная либо полная невозможность введения КИ, стали причиной создания национального клинического протокола оценки и лечения слуха пациентов, перенесших БМ у детей и взрослых в Голландии. Этот протокол является инструментом для всех медицинских и аудиологических специалистов. В таблице 1 представлен национальный Голландский клинический протокол, алгоритм проведения оценки слуха и лечения после перенесенного БМ у детей и взрослых (схема-1) [34].

В РК отсутствие в клиническом протоколе диагностики и лечения БМ - консультации специалиста сурдолога, приводит к позднему выявлению нейросенсорной тугоухости, которая завершается оссификацией и невозможностью проведения операции КИ и как следствие этого инвалидизация ребенка с полным отсутствием слуха.

На современном этапе недопущение развития инвалидности в виде полной потери слуха после БМ можно обеспечить путем оперативного вмешательства в виде кохлеарной имплантанции [28]. Причем, если пациенту кохлеарный аппарат имплантирован в раннем сроке до формирования 2 и 3 стадии оссификации, то это позволит полноценно восстановить слух. КИ является единственным эффективным методом восстановления слуха после поражения улитки при БМ. Необходимо помнить о том, что в РК существуют стандарты КИ у детей с НСТ слуха [33-37], согласно которым, пациенты, имеющие тяжелую степень тугоухости или глухоту после БМ, оперируются в срочном порядке [38].

Учитывая, что $10 \%$ БМ могут завершиться осложнением в виде нейросенсорной тугоухости, в клинические протокола по бактериальным менингитам у детей следует внести дополнения в виде консультации сурдолога в ранние сроки заболевания с последующим аудиологическим исследованием.

Сурдологи должны проверять всех детей, у которых был БМ, независимо от возбудителя. Существует четкая связь между бактериальным менингитом и потерей слуха $[39,40]$. Выявления НСТ и его мониторирования, с целью своевременного оперативного вмешательства в виде КИ, так как результаты КИ у лиц, перенесших менингит, зависят от распространенности процесса оссификации в улитке $[22,26]$ 
Ранняя диагностика НСТ при БМ путем скрининга слуха, дает возможность восстановить слух методом КИ и провести необходимые мероприятия при возникновении тяжелой потери слуха, что позволит ребенку слышать, говорить и жить полной жизнью.

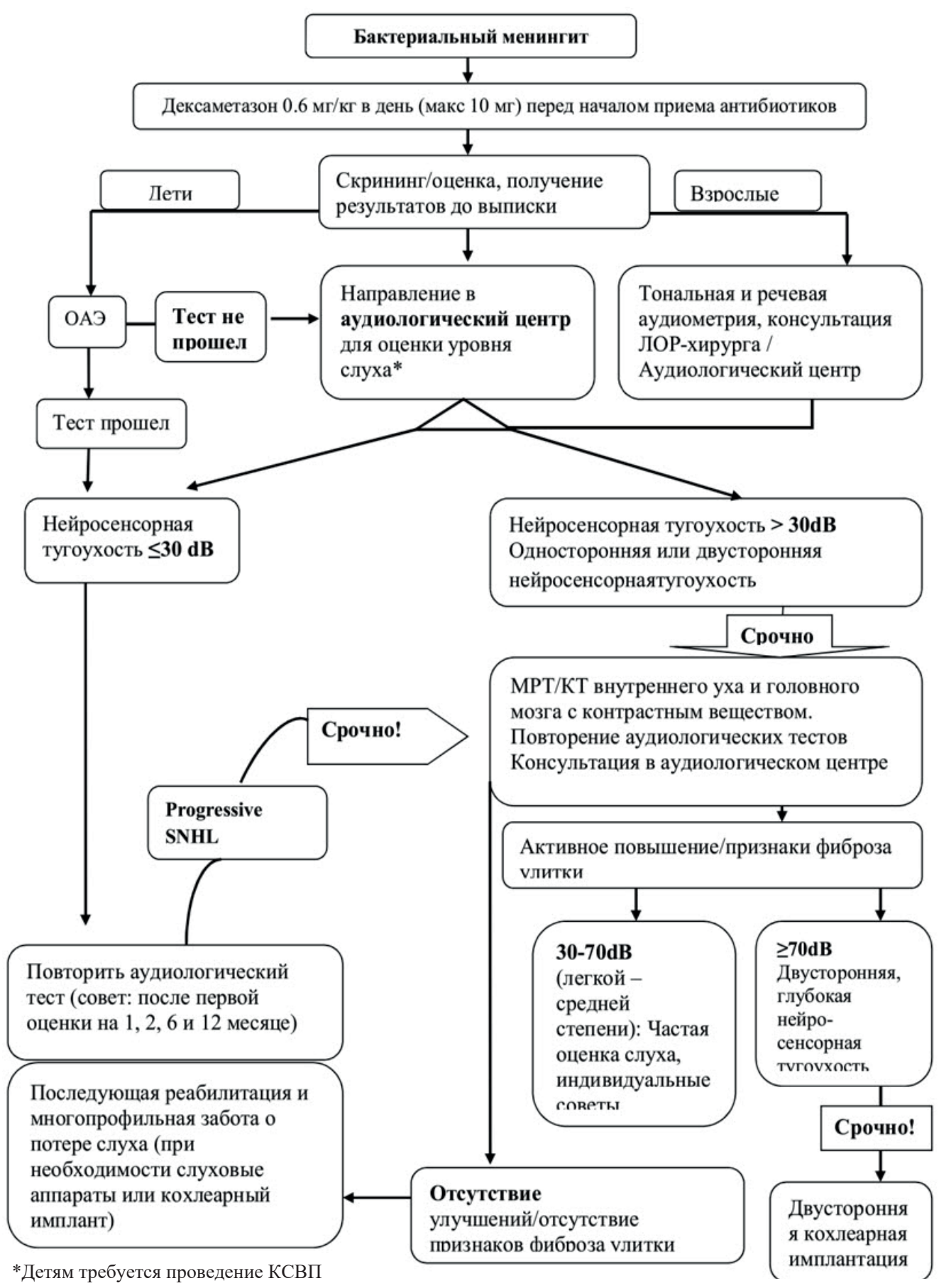

Схема-1 - Алгоритм протокол оценки и лечения потери слуха после бактериального менингита у детей и взрослых. Голландский клинический протокол (2010).

\section{Литература}

1. Morton N. Swartz. Bacterial Meningitis.A View of the Past 90 Year.Engl. J. Med. 2004; 351:18.1826.

2. Seidullaeva A.Zh. Epidemiologicheskaya kharakteristika bakterial'nykh meningitov u detei na sovremennom etape. (Epidemiological characteristics of bacterial meningitis in children at the present stage). Astanalyқ meditsina zhurnaly. 2017;2: 29-38.

3. Bhasin TK, Brocksen S, Avchen RN, Braun KV. Prevalence of four developmental disabilities among children aged 8 years: Metropolitan Atlanta Developmental Disabilities Surveillance Program, 1996 and 2000. US Department of Health and Human Services, Centers for Disease Control and Prevention. MMWR Surveill.Summ.2006; 55: 1-9. 
4. Kutz JW, Simon LM, Chennupati SK, Giannoni CM, Manolidis S. Clinical predictors for hearing loss in children with bacterial meningitis. Arch Otolaryngol Head Neck Surg. 2006; 132(9):941-945.

5. Van de Beek D, de Gans J, Spanjaard L, Weisfelt M, Reitsma JB, Vermeulen M. Clinical features and prognostic factors in adults with bacterial meningitis. New England Journal of Medicine. 2004;351(18):1849-59.

6. Wellman MB, Sommer DD, McKenna J. Sensorineural hearing loss in postmeningitic children. Otol Neurotol. 2003;24:907-912.

7. Koomen I, Grobbee DE, Roord JJ, Donders R, Jennekens-Schinkel A, van Furth AM. Hearing loss at school age in survivors of bacterial meningitis: assessment, incidence, and prediction. Pediatrics. 2003; 112:1049-1153.

8. Swartz MN. Bacterial meningitis — a view of the past 90 years. New England Journal of Medicine. 2004;351(18):1826-8.

9. Duan K, Guo J, Lei P. Safety and Immunogenicity of Pneumococcal Conjugate Vaccine in Preterm Infants: A Meta-Analysis. Indian J Pediatr. 2017; 84(2):101-110.11.

10. Isaacman DJ, McIntosh ED, Reinert RR. Burden of invasive pneumococcal disease and serotype distribution among Streptococcus pneumoniae isolates in young children in Europe: impact of the 7-valent pneumococcal conjugate vaccine and considerations for future conjugate vaccines. Int J Infect Dis. 2010; 14: e197-e209.

11. Richter SS, Diekema DJ, Heilmann KP, Dohrn CL, Riahi F, Doern GV. Changes in pneumococcal serotypes and antimicrobial resistance after introduction of the 13-valent conjugate vaccine in the United States. Antimicrob Agents Chemother. 2014;58:6484.

12. Türel Ö, Yıldırım C, Yılmaz Y, Külekçi S, Akdaș F, Bakır M. Clinical Characteristics and Prognostic Factors in Childhood Bacterial Meningitis: A Multicenter Study. Balkan Med J. 2013;30:80-4.

13. De Jonge RC, Van Furth AM, Wassenaar M, Gemke RJ, Terwee CB Predicting sequelae and death after bacterial meningitis in childhood: a systematic review of prognostic studies. BMC Infect Dis. 2010;10:232.

14. Koroljova M.A. Jepidemiologicheskij monitoring za gnojnymi bakterial'nymi meningitami v RF (Epidemiological monitoring of purulent bacterial meningitis in the Russian Federation). Diss. rabota. Moskva. 2014.

15. Daza, P., Banda, R., Misoya, K., Katsulukuta, A., Gessner, B.D., Katsande, R., et al. The impact of routine infant immunisation with haemophilus influenzae type $\mathrm{b}$ conjugate vaccine in Malawi, a country with high human immunodeficiency virus prevalence. Vaccine. 2006; 24:6232-6239.

16. World Health Organization. World health statistics 2015. World Health Organization; 2015 May 14.

17. Brouwer M. C., Tunkel A. R., and van de Beek D. Epidemiology, diagnosis, and antimicrobial treatment of acute bacterial meningitis. Clinical Microbiology Reviews. 2010; vol. 23, no. 3, pp. 467-492.

18. A. Davis and K. Davis, "Descriptive epidemiology of childhood hearing impairment," in Comprehensive Handbook of Pediatric Audiology. R. Seewald and A. M. Tharpe, Eds., ed San Diego: Plural Publishing, 2011; pp. 85-111.

19. L. J. Baraff, S. I. Lee, and D. L. Schriger. Outcomes of bacterial meningitis in children: a meta-analysis, Pediatric Infectious Disease Journal. 1993;2:389-394.

20. A. Chandran, H. Herbert, D. Misurski, and M. Santosham. dLong-term sequelae of childhood bacterial meningitis an underappreciated problem, The Pediatric Infectious Disease Journal. 2011.vol. 30, pp. 3-6.

21. E. Husain, R. Chawla, S. Dobson, and H. D. Davies, Epidemiology and outcome of bacterial meningitis in Canadian children: 1998-1999. Clinical and Investigative Medicine. 2006; 29:131-135.

22. D. Philippon, F. Bergeron, P. Ferron, and R. Bussi 'eres, Cochlear implantation in postmeningitic deafness. Otology and Neurotology.2010; 31, no. 1:83-87.

23. Kesser BW, Hashisaki GT, Spindel JH, Ruth RA, Scheld WM Time course of hearing loss in an animal model of pneumococcal meningitis. Otolaryngol Head Neck Surg. 1999; 120(5):628-637.

24. A. Douglas, H. Sanli, and W. P. R. Gibson. Meningitis resulting in hearing loss and labyrinthitis ossificans - does the causative organism matter. Cochlear Implants International. 2008; 9, no. 2: 90-96.

25. Hinojosa R, Redleaf MI, Green Jr JD, Blough RR. Spiral ganglion cell survival in labyrinthitis ossificans: computerized image analysis. The Annals of otology, rhinology \& laryngology. Supplement. 1995;166:51-4.

26. Rotteveel LJ, Snik AF, Vermeulen AM, Mylanus EA. Three-year follow-up of children with postmeningitic deafness and partial cochlear implant insertion. Clin Oto laryngol. 2005; 30(3):242-248.

27. M. Cosetti and J. T. Roland Jr. Cochlear implantation in the very young child: Issues unique to the under-1 population. Trends in Amplification. 2010; vol. 14, no. 1, 46-57.

28. Steenerson RL, Gary LB, Wynens MS. Scalavestibuli cochlear implantation for labyrinthine ossification. Am J Otol 1990;11(5):360-3.

29. Richardson MP, Williamson TJ, Reid A, Tarlow MJ, Rudd PT. Otoacoustic emissions as a screening test for hearing impairment in children recovering from acute bacterial meningitis. Pediatrics. 1998;102(6):1364-8.

30. Durisin M, Arnoldner C, Stover T et al. Audiological performance in cochlear implanted patients deafened by meningitis depending on duration of deafness. Eur. Arch. Otorhinolaryngol. 2008; 265:381-388.

31. Jöhr M, Ho A, Wagner CS, Linder T. Ear surgery in infants under one year of age: its risks and implications for cochlear implant surgery. Otology \& Neurotology. 2008;29(3):310-313.

32. Dvustoronnjaja nejrosensornaja tugouhost' (pediatrija). Respublikanskij centr razvitija zdravoohranenija (Two-sided sensorineural hearing loss). Klinicheskie protokoly MZ RK - 2014. Available at: http://www.rcrz.kz/index.php/ru/2017-03-12-10-51-13/ klinicheskie-protokoly

33. Ovchinnikov JuM, Borodin AA. Opyt operacii kohlearnoj implantacii s implantom Combi 40+ firmy «MED-EL» (Experience of 
operation of cochlear implantation with a Combi 40+ implant by MED-EL). Vestn. otorinolar. 2001(1):33-36.

34. P. Merkus, R. H. Free, E. A. M. Mylanus et al. Dutch cochlear implant group (CI-ON) consensus protocol on postmeningitis hearing evaluation and treatment. Otology and Neurotology. 2010; 31, no. 8: 1281-1286.

35. Szynczewska E, Chlebna-Sokół D. Immunogenicity of heptavalent conjugate vaccine against Streptococcus Pneumoniae in premature babies with low birth weight. Pediatr Neonatol. 2014;55:101-7.

36. JT. Roland Jr., M. Cosetti, K. H. Wang, S. Immerman, and S.B. Waltzman, Cochlear implantation in the very young child: longterm safety and efficacy. Laryngoscope, 2009; 119, no. 11: 2205-2210.

37. SJ. Dettman, D. Pinder, R. JS. Briggs, RC. Dowell, and J. R. Leigh. Communication development in children who receive the cochlear implant younger than 12 months: risks versus benefits. Ear and Hearing.2007; 28, supplement 2,11S-18S.

38. L. Colletti, M. Mandal a, L. Zoccante, R. V. Shannon, and V. Colletti. Infants versus older children fitted with cochlear implants: performance over 10 years. International Journal of Pediatric Otorhinolaryngology. 2011; 75, no.4: 504-509.

39. BCCH Audiology Clinical Practice Guideline Meningitis May 16, 2014. Available at: http://www.bcchildrens.ca/Audiology-Site/ Documents/BCCH_Clinical_Practice_Guideline_for_Audiologists_.pdf

40. Pashhina O.A «Osobennosti hirurgicheskogo jetapa kohlearnoj implantacii u pacientov, perenesshih meningit» (Features of the surgical stage of cochlear implantation in patients who underwent meningitis) Dis.na soikanie uchenoj stepeni k.m.n., SanktPeterburg, 2011;60-64.

How to cite this article: Aliya Seidullayeva, Gulnar Zhaxylykova, Dinagul Bayesheva, Raisa Sundetova, Bulat Aitzhanov, Almagul Orymbayeva. Sensorineural hearing loss after bacterial meningitis in children [in Russian]. J Clin Med Kaz. 2017;4(46):14-19. 